\title{
Notes on the genus Helvella, including the merging of the genus Wynnella
}

\author{
Harri Harmaja \\ Department of Botany, University of Helsinki, SF-00170 Helsinki, Finland
}

\begin{abstract}
Harmaja, H. 1974: Notes on the genus Helvella, including the merging of the genus Wynnella. - Karstenia 14: 102-104.

It is concluded that the few macroscopic features which alone separate or are commonly claimed to separate the genus Wynnella Boud. from Helvella Fr., are not valid at generic level, especially as all the microscopic characters, the anatomy of the excipulum and the spores, are commonly known to be exactly alike in these two genera. Wynnella is consequently merged with the older genus Helvella. For similar reasons the genus Underwoodia Peck is also considered congeneric with Helvella, which accords with the opinion of ECKBLAD (1968). The differences between the variety Helvella macropus (Fr.) Karst. v. brevis Peck and the typical $H$. macropus are considered to warrant the recognition of the variety at specific level. Three new combinations are made: Helvella silvicola (Beck in Sacc.) Harmaja, Helvella beatonii (Rifai) Harmaja, and Helvella brevis (Peck) Harmaja.
\end{abstract}

\section{Wynnella Boud.}

The monotypic genus Wynnella Boud. is acknowledged by all the present authorities on Pezizales (e.g., Nannfeldt 1966, Eckblad 1968, Dissing 1972, Smith Weber 1972, Korf 1972). The only species of this genus, W. silvicola (Beck in Sacc.) Nannf. (Otidea auricula auct.), whose correct specific epithet was discovered by NANNFELDT (1966), was for a long time previously generally referred to Otidea, solely on account of its ear-shaped apothecia. As it was found that all its microscopic characters, the spores (including their number of nuclei) and the excipulum were widely different from those of Otidea, Boudier's decision to remove it from that genus was generally approved. It might have been expected that this time more importance would be accorded to the microscopic than to the macroscopic characters, and that the species would be included in Helvella, since all are agreed that microscopically nothing separates Otidea silvicola from Helvella.
However, the microscopical features were once more underestimated in favour of a few slight macroscopical differences; the species was considered to deserve a genus of its own and kept apart from Helvella.

Three reasons for maintaining Wynnella are given in the papers mentioned at the beginning of this article. The first is the shape of the apothecium. However, in the present-day taxonomy of the Pezizales it is widely and, to my mind, correctly believed that a natural classification is best achieved by giving the microscopic characters preference over the macroscopic ones (especially the ascocarp shape). Indeed, this principle is exemplified by the present widely approved concept of Helvella! Why could not $W$. silvicola be included in that genus, where the apothecium shape already shows wide variation? Furthermore, the apothecium of $H$. leucomelaena is known to be often somewhat irregular in shape and even split into lobes (see e.g. 
Dissing 1966). Wichanský (1959) has studied this variation which led him to describe one new variety with six forms (fortunately none of these unimportant taxa has been published validly since that author fails to designate type specimens for them). One of these forms he even named f. otideata as its apothecium was split like that of most species of Otidea! In Otidea species with regularly cupulate apothecia (e.g. O. indivisa Vel.) are commonly included along with species with split more or less ear-shaped apothecia, since the spores and anatomical characters in both groups of species are of exactly the same type (see e.g. Harmaja 1974).

Secondly, the red-brown colour of the ascocarp of $W$. silvicola is often considered to prevent its transfer to Helvella. Colour differences should be used most carefully at the generic level (Helvella comprises already black, brown, grey and white species!), and the colour difference between $W$. silvicola and e.g. $H$. leucomelaena and $H$. acetabulum is not great. In this connection, great interest attaches to Dissing's (1972) observation that the colours of $W$. silvicola are similar to those of Acetabula aestivalis Heim \& Remy, which he intends to transfer to Helvella, in a joint paper with Dr. A. Raitviir.

The third difference said to exist between Wynnella and Helvella is the consistency of the dried ascocarps, wsich have been described as »horny» in the former genus (e.g. by NAnnfeldt 1966 and Dissing 1972). I have seen dry fruit bodies of $W$. silvicola, and I am not at all sure whether they differ in consistency from those of e.g. H. leucomelaena and $H$. acetabulum. In no case can the difference be considered distinct or significant. Nothing can be observed in the anatomical characters of $W$. silvicola that could account for this supposed of true hardness; the hyphae are of the same type as those of Helvella, reviving easily and not being agglutinated or collapsed. This point does not strike me as having any relevance at generic level.

The base of the apothecium of $W$. silvicola is usually slightly grooved as in $H$. leucomelaena.

I am convinced that Wynnella silvicola has such close affinities to Helvella that it is best included in that genus. It is perhaps most closely related to $H$. leucomelaena (and probably even closer to Acetabula aestivalis). The following new combination is accordingly proposed: Helvella silvicola (Beck in Sacc.) Harmaja, n. comb. (Otidea silvicola Beck in Sacc., Sylloge Fungorum. .. 8: 97. 1889. - Wynnella silvicola (Beck in Sacc.) Nannf., Ann. Bot. Fennici 3: 309. 1966.)

\section{Underwoodia Peck}

Following the principle that at generic level most diagnostic value should be accorded to the sporal and anatomical characters, and not to the ascocarp shape, I also consider that the genus Underwoodia Peck is unnecessary, and should be merged with Helvella. This view agrees completely with that of EakBLAD (1968). The clavate, internally chambered Underwoodia ascocarp, with the hymenium appressed to the upper part, can fairly readily be seen to differ comparatively little in principle from the Helvella lacunosa type of ascocarp. The famous sparassioid form of Peziza proteana, repeatedly described as a new genus, as well as certain other cases, prove convincingly that in the Pezizales very small genetic changes may very radically affect the ascocarp shape, resulting in superficially very different fruit bodies, not only in the same genera but even within the same species. Helvella contains very different types of ascocarp as already stated above, and as regards the subdivision of the genus, it should not be forgotten that, although not used in e.g. the commonly approved subdivision of Dissing (1966), the subgeneric category is fully available. The following new combination is proposed: Helvella beatonii (Rifai) Harmaja, n. comb. (Underwoodia beatonii Rifai, Verh. Koninkl. Nederlandse Akad. Wetensch., Afd. Natuurh. II : 57(3) : 69.1968 - Holotype [K] studied.) 


\section{Helvella macropus v. brevis Peck}

In her excellent study on Helvella SмiтH WEBER (1972) has shown that the variety brevis differs distinctly from the typical $H$. macropus in its macroscopic, microscopic (the spores are shorter and broader) and ecological characters. She accepted Peck's original opinion and treated the taxon as a variety, but I consider that these differences warrant a separation from $H$. macropus at the specific level. (The same may apply to some other races of the apparently collective species $H$. macropus, e.g. the Jamaican collection cited in Dissing \& Nannfeldt 1966.) When studying Peck's type I found it possible that a careful study on larger material might unmask slight differences also in the paraphyses and the ectal excipulum. The following new combination is accordingly proposed: Helvella brevis (Peck) Harmaja, n. comb. (Helvella macropus (Fr.) Karst. v. brevis Peck, Bull. Torrey Bot. Club 29: 74. 1902. - Holotype [NYS] studied.)

Acknowledgements. - I. am indebted to Dr. John H. Haines (NYS) for placing at my disposal the type of Helvella macropus v. brevis and the Director of the Herbarium and the Royal Botanic Gardens at Kew (K) for lending the type of Underwoodia beatonii.

\section{REFERENCES}

Dissing, H. 1966: The genus Helvella in Europe with special emphasis on the species found in Norden. - Dansk Bot. Ark. 25: 1-172.

- 1972: Specific and generic delimitation in the Helvellaceae. - Persoonia 6: 425-432 +23 .

Dissing, H. and Nannfeldt, J.A. 1966: Helvella cupuliformis sp. nov., $H$. villosa (Hedw. ex O. Kuntze) comb. nov., H. macropus (Pers. ex Fr.) Karst., and their allies. - Svensk Bot. Tidskr. $60: 325-337+$ I-III.

EGKBLAD, F.-E. 1968: The genera of the operculate Discomycetes. A re-evaluation of their taxonomy, phylogeny and nomenclature. - $\mathrm{N}$. Mag. Bot. 15: 1-191.

Harmaja, H. 1974: The generic limit between
Otidea and Tarzetta (Pustularia auct.). Karstenia 14: 138-142.

Korf, R.P. 1972: Synoptic key to the genera of the Pezizales. - Mycologia 64: 937-994.

Nannfeldt, J.A. 1966: On Otidea caligata, O. indivisa and $\mathrm{O}$. platyspora (Discomycetes Operculatae). - Ann. Bot. Fennici 3: 309 -318 .

Smith Weber, N. 1972: The genus Helvella in Michigan. - Michigan Bot. 11: 147-201.

Wichanský, E. 1959: Nová odrůda kališníku bĕločerného Acetabula leucomelas Pers. var. semihypogea Wich. odr. polopodzemní. Acetabulae leucomelantis Pers. varietas nova: var. semihypogea Wich. - Česká Mycol. 13: 20-25. 